beet, and on the distribution of aluminium in Nature and its significance in the cultivation and metabolism of plants. In later years he studied the influence of iodine on the growth and development of plants and also the effect of radioactivity upon metabolic processes in plants and animals.

Stoklasa was professor at the Technical High School in Prague, director of the State agricultural experimental station and vice-president of the Czechoslovak Academy of Agriculture.

\section{Prof. Georg Wiegner}

IT is with great regret that we have to announce the death on April 14 of Prof. Georg Wiegner, of the Agricultural Institute, Eidgenössische Technische Hochschule, Zurich. He had for some time been suffering from gastric ulcers, and underwent an operation which appeared to be successful, but peritonitis set in and ended fatally.

Wiegner was born in Germany, and received his training under Zsigmondy in Göttingen, then went straight to Zurich as professor of agricultural chemistry. Here he remained all his life, excepting that during the War he was temporarily in Germany for military service, and was wounded at least once. It is an open secret that he had been invited to a much more important chair outside Switzerland, but he preferred to remain in Zurich where, he said, he had been cordially received as a young and unknown man, and had familiarised himself with the agricultural problems of the Swiss farmers and discovered ways in which he could help them.

As might be expected from his training, Wiegner turned early to the study of the colloidal properties of the soil. It was at that time widely supposed, as the result of investigations by Way and by van Bemellen, that base exchange and some at any rate of the colloidal properties were due to zeolites in the soil. Wiegner took advantage of the possibility of obtaining permutite and other zeolites in quantity to make detailed studies by the new methods on base exchange, its nature and relation to the colloidal properties of the zeolite and of the clay, especially dispersion and flocculation, and he was able to work out an electrical hypothesis which threw considerable light on the whole phenomena. In the end it was shown in his laboratory that clay did not behave like permutite, and his hypothesis enabled him to explain the differences.

In 1930 Wiegner was invited to England to lecture at certain of the agricultural institutions so that members of the staffs might have the advantage of hearing his views and discussing problems with him. His lectures were published in the Journal of the Society of Chemical Industry for 1932 and constitute an admirable summary of the more important properties of clay and of zeolites.

In addition to these colloid investigations, Wiegner found time to study animal nutrition, choosing practical problems such as the drying and ensiling of grass, a very important matter in Switzerland; the evaluation of feeding stuffs with special reference to starch equivalents and gains in weight; and other subjects of farming interest. This work had the same high quality that characterised his soil investigations.

It was, however, as a teacher that Wiegner was supreme. He would come into the laboratory, call his research students together and start discussing some new idea, either his own or one of theirs, or he would sketch out some new experiment, and he would expect everyone to join in as eagerly as himself. On Saturday afternoons he would take a number of his postgraduate students for an excursion during which long discussions took place, lasting sometimes six hours or more, much of it in a village inn over beer, bread and cheese. The subjects were not necessarily scientific, but might even be political, and as his students came from many different countries and felt themselves entirely free and unconstrained, the discussions were often extremely interesting.

At the Congresses and Commission meetings of the International Society of Soil Science, Wiegner was always an outstanding personality; his geniality and kindliness towards his colleagues and his students endeared him to all who knew him. He added lustre to the Technische Hochschule of Zurich and he will long remain in the memory of his friends.

E. J. RuSSELL.

WE regret to announce the recent death at the age of fifty-eight years of Dr. Ernest Lobstein, dean of the faculty of pharmacy and professor of materia medica at Strasbourg, member of the Paris Academy of Medicine, and author of studies on the biology of the tubercle bacillus and chemical analysis of the mineral waters of Alsace, Bulgaria and Palestine.

WE regret to announce the following deaths :

Dr. William Bradley Coley, formerly professor of clinical surgery at Cornell University Medical College, New York, well known for his treatment of sarcoma by means of erysipelas and prodigiosus toxins, aged seventy-four years.

Prof. L. Frédericq, emeritus professor of physiology in the University of Liège, aged eighty-five years.

Dr. Alfred Palmer, one of the founders, and from 1926 until 1930 president of the Council, of the University of Reading, on May 20, aged eighty-three years.

Sir Robert Rait, C.B.E., principal and vicechancellor of the University of Glasgow since 1929 , on May 25, aged sixty-two years.

Mr. Arthur J. Weed, known for his work on seismology in the University of Virginia, on April 15, aged seventy-five years.

Errata. Obituary of Prof. Karl Pearson (May 23, p. 857): Mr. Udny Yule informs us that the dates of Prof. Pearson's books should read as follows : "Grammar of Science", 1892; "Chances of Death, etc.", 1897 ; "Ethic of Free-thought", 1888. 